\title{
THE WAVE OF MIGRATION IN EUROPE AS A CAUSE OF TERRORIST THREAT
}

\author{
Tomasz BĄK \\ Wyższa Szkoła Informatyki i Zarządzania w Rzeszowie, Rzeszów, Poland \\ tbak@wsiz.rzeszow.pl
}

\begin{abstract}
The article presents the migration wave in Europe as the cause of terrorist threats. The conflicts in the Middle East, particularly in Iraq and in Syria, increase the numbers of refugees from those areas and their migration to European countries, mainly EU members. That wave is used by terrorist organisations to smuggle members of those organisations to Europe in order to prepare terrorist attacks. The author also indicated the difficulty in controlling such a huge wave of refugees in the aspect of ensuring security in European countries.
\end{abstract}

\section{Keywords: human migration, refugees, war, security, terrorism}

\section{INTRODUCTION}

The $20^{\text {th }}$ century was not only the time of two world wars but also a time of mass migrations, escapes, displacements and deportations, and serious threats related to those phenomena. It is estimated that due to forcible migrations, caused by various factors, about 50 million European citizens were removed from their homes. At the same time it should be kept in mind that such a phenomenon was not a new one, as it can be traced back to the beginnings of humanity.

It seemed that the onset of the $21^{\text {st }}$ century, together with the end of the Cold War, would put an end to migrations within Europe for good. However, that has not happened.

In the last five years at least 17 conflicts broke out: 10 in Africa (Republic of Côte d'Ivoire, Central African Republic, Egypt, Tunisia, Libya, Mali, Nigeria, Democratic Republic of the Congo, South Sudan, Burundi), 3 in the Middle East (Syria, Iraq, Yemen), 3 in Asia (Kirgizstan, Burma/Myanmar, Pakistan) and 1 in Europe (Ukraine).

A wave of illegal migration from the Middle East and from Africa which resulted from those conflicts became a particular problem for Europe.

\section{MIGRATIONS AND THEIR FEATURES}

To correctly understand the issues of migration, first its definition should be specified.

Migrations are any and all movements leading to a permanent or temporary change of people's dwelling place. Migrations are considered the major manifestation of the spatial mobility of people.

The currently most frequent causes for migration are:

- economy - emigration aimed at improving the standard of life, sometimes to a country of a better economic status. Usually such a journey is related to a labour market being opened to foreigners, as it was in the case of Poles leaving for work within the European Union, or to the need for seasonal workers or workers ready to take on tasks which are difficult or unpopular among the host country's dwellers. That concerns also internal migrations, e.g. movement of citizens of 
the same country from villages to cities with the aim of finding or changing work; - business - career-related emigration to a country which offers a legal employment possibility, but the host country's status does not have to be higher than the status of the country of origin; concerns e.g. foreign language teachers or business people;

- education and research - trips to a country which offers educational or research opportunities, e.g. for foreign students, scientists, researchers;

- security - often caused by armed conflict, change of government, change of country's borders (frequently related to persecution where the ethnic origin or religion is the cause for harassment). Some decide to escape due to violence, a sense of threat, or human rights violation, seeking shelter in a place where they can feel safe and free;

- environmental reasons - leaving areas in particular danger of a natural disaster or areas of drinking water shortage, which are turning into deserts [1].

Other criteria which also decide on the division of migration are [2]:

- Duration of the migration:

$\checkmark$ Permanent - changing residence for an unspecified time;

$\checkmark$ Temporary - changing residence for a specified time, e.g. during studies, for seasonal work, etc.;

$\checkmark$ Circular - a particular type of migration movement, where people move back and forth every day, e.g. from and to work or school, etc.

- Area of migration:

$\checkmark$ Internal migration - changes of permanent or temporary residence where people cross the administrative border of a given territorial unit in order to settle permanently or temporarily in a different unit within the same country;

$\checkmark$ External migration - crossing the country's border, related to a relatively permanent change of residence.
Various streams of migration flow can be distinguished [3]:

$\checkmark$ Internal:

- migration from the

countryside to cities;

- migration from cities to the

countryside;

- migration from a city to

another city;

- migration within the countryside, from village to village.

$\checkmark$ External - related to crossing country borders, which includes:

- emigration - going abroad

for a permanent stay;

- immigration - coming to a

country from abroad for a permanent stay;

- re-emigration - return of

emigrants to their home country after a permanent stay abroad [4];

- repatriation - mass return of POWs, internees and people who left their country for e.g. political reasons, to their home country, organized by state authorities[5];

- deportation - forcible removal of (most frequently) illegal immigrants from the country [6];

- expatriation - leaving one's country voluntarily or under compulsion (breaking with the country).

- Organisation and course of migration [7]:

$\checkmark$ Individual;

$\checkmark$ Group;

$\checkmark$ Planned;

$\checkmark$ Forced by natural disaster occurring or threatening;
$\checkmark$ Legal;
$\checkmark \quad$ Illegal;
$\checkmark$ Voluntary;
$\checkmark$ Forced.

2. ARAB SPRING IN AFRICA, SYRIAN AND IRAQI CONFLICTS AS CAUSES FOR MASS MIGRATION TO EUROPEAN UNION COUNTRIES.

In December 2010, unemployment, growing food prices, corruption and 
nepotism forced citizens of Arab countries to go out in the streets. It started in Tunisia, then the Arab Spring extended to encompass Algeria, Libya, Jordan and other countries of northern Africa and Middle East. The civil war in Syria, lasting since 2011, caused the death of several hundred thousand people. Bloody fights forced about 13 million Syrians to leave their homes. Similarly, al-Gaddafi's rule and his subsequent overthrow and destabilisation in the country led to an increased migration from Libya.

Europe, and more precisely European Union countries (in particular due to the freedom of movement within the EU), are the most desired direction of migration, particularly regions which are relatively close geographically. Many European countries are viewed as rich. What is more, all are signatories to the Geneva Convention, which imposes the obligation to provide shelter to people applying for a refugee status. Therefore, Europe became the main direction of escape for citizens of North and East Africa and the Middle East.

For months now, Europe has been struggling with the greatest migration crisis in modern history. By the end of August, over half a million people have arrived to the continent from the Middle East, Africa and the Balkans. For many reasons mentioned below in this article, that puts the security of European states and the existence of the Schengen area under threat.

The current crisis results mainly from the wars and instability in the Middle East and Africa. The process of migrant flow to Europe had its beginnings at the onset of the new millennium. Like in the previous century, large-scale conflicts were one of the causes of the current situation. That refers to the Middle East, which was destabilised with the attack on Iraq in 2003, the civil wars raging since 2011 in Syria and Libya and the emergence of the so-called Islamic State in 2014. The list should further include the war in
Afghanistan and Iraq (since 2003) and the bad situation in Iran. Another reason arose in Sub-Saharan Africa. The dictatorship in Eritrea and the general poverty of the region are problems which no one seems to be able to handle right now.

And it is those who escape war and persecution - Syrians, Afghans, or Eritreans - that constitute the majority of today's newcomers to Europe. But not only have they decided to take the deadly risk of crossing the Mediterranean Sea. One of the more numerous migrant groups are the Nigerians, who in the vast majority of cases do not receive a refugee status. Although their country is torn by the war with the jihadists from Boko Haram, the war covers a relatively small and scarcely populated area in the northeast of the country. Additionally, in the recent years Nigeria has been experiencing a period of strength growth and is currently a major economy of the continent.

The conflicts still smouldering at the neighbouring continents make the number of people escaping from their home towns and villages grow yearly. Their alternative is Europe. European countries are a popular destination despite the cultural gap and utter foreignness of the Western lifestyle. The Old Continent will pay a high price for its attractiveness, though not only for that. The migration wave which started at the beginning of the $21^{\text {st }}$ century had reached its peak in 2015 .

In the first six months of 2015 Europe saw the coming of 150 thousand migrants - and that is counting only those coming across the sea - which is $83 \%$ more in comparison with the same period in 2014. That has caused one of the greatest crises ever faced by the European Union. It is possible, however, that this is only the beginning of a migration wave to the Old Continent.

In the context of the immigrant/refugee situation, the following routes to European Union countries may be distinguished [8]: 
- the western (Mediterranean) route through the border with Spain, crossed by 6.7 thousand citizens of Syria, Guinea, the Ivory Coast,

- the central (Mediterranean) route through the border with Italy, crossed by 110 thousand citizens of Eritrea, Nigeria, countries of Sub-Saharan Africa,

- the eastern (Mediterranean) route through the border with Greece, crossed by nearly 200 thousand citizens of Syria, Afghanistan, and Pakistan,

- the Balkan route - through the SerbianHungarian border, crossed by over 140 thousand citizens of Syria, Afghanistan, and Kosovo,

- the eastern European route - through the border with Poland, crossed by 717 citizens of Vietnam, Afghanistan, and Georgia.

Tab. 1. Migrants coming by the sea to EU

\begin{tabular}{|c|c|}
\hline Syria & 66698 \\
\hline Eritrea & 34323 \\
\hline $\begin{array}{l}\text { Unspecified nationalities } \\
\text { from Sub-Saharan Africa }\end{array}$ & 26341 \\
\hline Afghanistan & 12687 \\
\hline Mali & 9789 \\
\hline Gambia & 8642 \\
\hline Nigeria & 8490 \\
\hline Somalia & 7440 \\
\hline Palestine & 6418 \\
\hline Senegal & 4769 \\
\hline Morocco & 116 \\
\hline Other & 34597 \\
\hline Total & 220194 \\
\hline
\end{tabular}

Source:

https://pl.wikipedia.org/wiki/Kryzys_migra cyjny_w_Europie

In 2014, 600 thousand people were seeking asylum in the EU. 55\% applications for asylum were refused in that year. From the beginning of 2015 until the end of August, over 310 thousand refugees came to European countries. About 200 thousand of them went to Greece, and 110 thousand - to Italy. In 2014, the Hungarian Immigration and Civic Office registered 42777 applications for asylum. The migrants cross the Mediterranean Sea by two routes: through Italy and Malta and through Greece and Bulgaria to Cyprus. Between $1^{\text {st }}$ January and $31^{\text {st }}$ July 2015, in Germany, 195723 applications for asylum were submitted. $21.5 \%$ from people from Syria, $15.3 \%$ from Kosovo, 15\% - from Albania, 5.9\% from Serbia, 5.4\% from Iraq, 5.2\% from Afghanistan, 2.8\% from Macedonia, 2.5\% from Eritrea, $1.7 \%$ from Nigeria and Pakistan, and $23 \%$ from other countries or from people whose origin is unknown or doubtful.

One of the major effects of migration is what migrants do when reaching their target country. Frequently the performed jobs depend on the purpose of migration to the particular country. Business people usually work in positions in which they have better development opportunities than back home. Students, besides learning, take temporary jobs or language courses. Economic immigrants coming to countries of a higher economic status accept any work which allows them to earn a living for themselves and/or their family, and often to return home. Most immigrants do physical labour, often below their professional qualifications. Immigrants often fill a professional gap in the given labour market, working in professions which are in demand in the particular country, but which are less attractive for the locals. They are hampered in getting a better job by issues such as language competence, recognition of diplomas and educational qualifications from foreign institutions, and legal requirements and costs related to legal employment of a foreigner.

Migrations are a phenomenon which includes many thematic areas with impact on social, economic and political processes. The consequences of migration 
within various areas of life: social, professional, individual, can be divided as follows:

- legal and political (establishing national and international laws and documents regulating migration, e.g. concerning legalising the stay),

- economic (e.g. impact of the immigrants on the labour market), social (e.g. movement of people over the given area, which influences new social relations and ties),

- cultural (e.g. the mixing of various cultural groups, creating a multicultural society),

- psychological (e.g. adapting to new living conditions among different people, a new environment and new culture),

- humanitarian (e.g. ensuring safety to various groups of people).

People who migrate need help both when moving and reaching their destination. The first issue is ensuring means of transport which will help them reach their target. As shown by many stories of refugees, the way can be very difficult. The next step is settling issues related to legalising the stay - yet is it not always possible, so the migrants remain with an undetermined status in the particular country, which means that deportation is a constant threat. Further steps are related to stabilising the professional situation (looking for work that will allow them to earn a living) or ensuring an independent status (legalising the stay).

Depending on how those steps proceed, areas of aid will be different for each foreigner - and thus, some will seek help in settling administrative business (cooperation with clerks, lawyers, sometimes the police), others will seek help concerning their own safety (cooperation with doctors, psychologists, night-shelters, help in finding work), yet others will seek help for their families (e.g. information how to support their families financially or how to ensure school for the kids who came with them). A large and important area where foreigners may need help from their hosts - both authorities and individuals - is integration in the society. It usually starts with learning the language, followed by learning the new culture, rules of interaction, contact with the local inhabitants and gradual involvement in the life of the local community. To have the newcomer's effort in learning the language, culture and social interaction rules bring fruit, it must fall on "fertile ground". Central and local authorities as well as the community can prepare themselves for the presence of people from other countries who wish to stay and be part of the community of the host country. That means that they are given the same rights as those of the other inhabitants, equal, qualification-based treatment in access to the labour market, and the right to express their beliefs or practice their religion.

\section{IMPACT OF MIGRATION ON THE} SECURITY OF THE EUROPEAN UNION AREA - TERRORIST THREAT.

Modern migration movements are currently becoming an issue of international relations which is typical for a growing number of countries.

Migration movements in the European Union which have the greatest implications for national and international security are external migrations to the EU area.

We are thus dealing with a steadily growing dynamics of people's migration to the European Union area. It should be noted that France has so far had the greatest problem with such migrations as a country. Due to its geographical position and colonial past, it faces significant difficulties in controlling the coming of people from the Maghreb countries to its territory. It is noteworthy that despite an extensive (at least until recently) social welfare granted to such migrants by France, the issue is becoming a serious 
social problem in that country. The situation in Germany looks no better.

The negative results of migration for security:

- Decline of national identity - the phenomenon of migration contributes to the weakening of local customs and traditions, and weaker independence of particular countries. A factor which escalates that process is today's over liberal assimilation policy (granting permanent residence cards or citizenship to non-assimilated people generates conflicts of a racial and ethnic nature). Ethnic ghettos appear - foreign enclaves, which leads to tension and decreases the sense of safety of the native people in their own country. Moreover, the worldwide unification mixed with international migration leads to the unification and McDonaldisation of the world, and that is destructive for the sense of distinctness and uniqueness of the particular nations and their cultures. As a result, it is difficult to set the boundaries of particular civilisations and national identities. The contemporary national state begins to show lack of inner balance (aggressive behaviour of ethnic minorities), and a conflict between the universalism of human rights and civic rights and duties;

- Economic dangers - the phenomenon of mass economic migration brings with it such risks as: losing qualified labour force and the resulting decrease in the quality of basic services, losing people of a rich development potential (brain drain), ageing of society (decreased demographic potential), decreasing economic growth and work productivity due to the outflow of specialists, decreased tax revenue in the country sending the emigrants (lower return on investment in public education), strengthening of the economy based on money sent from abroad and later economic crisis when the transfers cease, and strengthening of the peripherality of the country in the international economic order. For host countries, positive consequences of the migration process for their security are visible in better economic growth, gaining qualified employees, rejuvenation of the society (birth rate), gaining cheap labour force, increased production and consumption;

- Threats to civilisation and culture unification, the element of which is international migration, creates a problem for the state's guarantee of cultural and civilizational security for their citizens. Mass migration processes pose a threat to the national culture, as they mean a clash of different cultures and identities. The inflow of a large number of immigrants to the country and their increased demographic potential within the host country generate a potential for conflicts of identities of alien civilisations, which poses a threat to internal security (too frequent inter-civilisation interactions). The process generates an asymmetric conflict between the organised host country and a minority without a recognised representation, whose main potential is high birth rate and strong cultural integration. There appears the unsolved problem of migrants' cultural integration - a low degree of immigrant assimilation, together with the need for the government to follow an equal-rightsbased policy promoting a multicultural society with all its consequences, which must lead to changes in the cultural identity of the host society. Reactions to that phenomenon often include xenophobia, nationalism, racism and general dislike of foreigners;

- Terrorism and transnational organised crime - especially after $11^{\text {th }}$ September 2001, the issue of migration started to be considered in the context of security - both domestic and international. The impact of migration on international terrorism, organised crime, human, arms and drug trafficking was noticed. The emergence of immigrant-multicultural societies creates favourable conditions for the activity of criminal, terrorist, extremist and separatist groups, which is a threat to domestic security. Fighting those phenomena 
involves tighter border control, restrictive visa policy, modern technologies application for identity verification, a professional database, a creation of a system for information exchange within international cooperation. The fight against the phenomena is complicated due to information globalisation, open borders (Schengen area), free movement of people, services, goods and capital. Those factors foster a more intensive process of illegal migration, which poses a terrorist threat and also provides activity and development opportunities for organised crime [9].

The impact of migration on the security of the European Union may be various. Migrants are one of the groups from which members of transnational crime organisations may come. In many countries, emigrant communities are associated with drawing profits from prostitution, drug dealing or the increase of radical tendencies (fundamentalist, terrorist movements). However, it cannot be stated that the disadvantages of external migration into Europe are not compensated for by its advantages. Paradoxically, most migrants work hard and effectively, which contributes to maximising the economic security of the states they are employed in, and thus to the economic security of the whole continent. By money transfers abroad, they also directly increase the economic security of their home countries.

However, the most common problem are attempts of terrorist organisation members to infiltrate Europe, to then organise structures, prepare and conduct terrorist attacks there. Such a plan is followed e.g. by the terrorist organisation called the Islamic State (ISIS). ISIS officially stated that it was against the emigration of Muslims and that that was a sin and a forbidden deed (haram) in Islam [10]. That is, however, only a bluff. In fact, such a turn of events is convenient for ISIS. The current migration paralysis is finishing Europe from inside. It may cause both economic and social degradation. People turn to right-wing ideas, nationalism spreads, along with religious extremism, fanaticism and dissatisfaction, moods are growing more radical - the Islamic State feeds on that. It is the perfect basis for recruitment of new European Daesh fighters.

Correct identity verification of the incoming migrants is difficult. Such a situation makes things significantly easier for terrorists. Just like economic migrants, they can present themselves as Syrians persecuted by the Islamic State, while in reality they work for it.

Moreover, in the recent days, the Western media have published a talk with one of the warriors of the Islamic State. He confirmed that over 4000 fighters related to the Islamic State have been smuggled into the Western countries so far, hidden among other refugees from the Middle East. That is an element of the Islamists' plan aimed at infiltrating the Western countries and, in the long term, establishing a worldwide caliphate. About 20 percent of the refugees heading for Europe may belong to groups related to the Islamic State.

The Islamic State makes its presence known in Europe by organising e.g. the attacks in Paris $\left(13^{\text {th }}\right.$ November 2015) and Brussels ( $22^{\text {nd }}$ March 2016) in response to the air raids on ISIS positions in Syria and Iraq [11].

The Islamic State has published a propaganda film in which it threatens the countries fighting against ISIS. The enemies listed included Poland. The Islamists announce further attacks to come. They threaten mainly Iran, Turkey and Russia. They also go against almost all of the countries who fight against the Islamic State or support the air raids. The countries currently facing the highest terrorist threat are Tunisia, France, Belgium, and Sweden. Particular caution is advocated when visiting those countries.

In the film, the Islamic State also states that it is tolerant (showing e.g. pictures of black fighters), but only towards Allah followers. 
The Islamists warns their enemies that the fight will cost them more and more each year. ISIS presents a list of countries which are in a coalition against the Islamic State and threatens to burn them "on the hills of death".

The Islamic State changes its tactics in Europe: it is going to send to the particular countries terrorists who are not those countries' citizens. They are more difficult to discover for the local forces. So far, the nightmare of the European organs combatting jihad terrorism were Muslims who were radical, but also perfectly integrated with the local community, EUborn, with nothing distinguishing them from other citizens, their radicalism hidden. That radicalism usually came from online indoctrination, the force and effectiveness of which the organs did not appreciate enough at first.

Later a different type of threat appeared: young citizens of some EU member countries leaving to fight on the side of the Islamists in Afghanistan, Iraq, and in particular in Syria. There they go through ideological indoctrination and military training. On return to their European home countries, they make perfect candidates for attackers.

Today, ISIS forces in Syria and Iraq include hundreds, and maybe even thousands of Europeans.

The forces try to detect all people returning to Europe to observe them carefully.

Islamic radicals have already realised that the forces of the particular European countries have a quite good orientation by now in what happens in their own territory and who may present a threat. But jihad organisers in Europe also noticed that local forces do not exchange information about the issue quickly and effectively enough. If for example a potentially dangerous French citizen enters France, the local forces will almost certainly get him or her in their sights at once. But if the person is a citizen of a different country, s/he may more easily slip through the net. We might be facing the threat of "migratory terrorists" who may appear everywhere but in their country of residence [12].

\section{SUMMARY}

Steps are taken at the level of EC law to protect the common market from uncontrolled migrations, the smuggling of goods, transnational organised crime, and mainly from terrorism. One of the major initiatives aimed at preserving security within the European Union has been the establishment of the European Agency for the Management of Operational Cooperation at the External Borders of the Member States of the European Union (FRONTEX). Some steps towards maximising security are also taken within initiatives concerning EC law (Acquis Schengen). Yet the greatest possibilities in that respect lie in the laws of the member states (migration and asylum policies of the particular countries are subject to EC law only in a limited scope). Hence the European Union countries are facing a great task of stopping the still growing wave of illegal migration, and mainly of fighting the threats it brings with it, mainly that of terrorism.

[1] After: K. Białek, Migracje na świecie (Migration in the World), http://www.ceo.org.pl/pl/migracje/o-migracjach [23.03.2016]

[2] http://www.demografia.uni.lodz.pl/dlastud/migracje.pdf, [23.03.2016]

[3] Ibid.

[4] http://www.demografia.uni.lodz.pl/dlastud/migracje.pdf, [23.03.2016]

[5] http://www.repatriacja.pl/, [23.03.2016]

[6] Cf. http://www.migrant.info.pl/Deportacja.html, [23.03.2016] 
[7] A. Staszczyk, Skutki migracji dla bezpieczeństwa wewnętrznego (Migration Consequences for Internal Security), [at:]

http://edb.wsie.pl/files/3313/5288/1199/Skutki_migracji_dla_bezpieczestwa_wewntrznego.pd $\mathrm{f}[23.03 .2016]$

[8] Estimates of the Office for Foreigners, September 2015, for the first half of 2015.

[9] A. Staszczyk, Skutki migracji dla bezpieczeństwa wewnętrznego (Migration Consequences for Internal Security), [at:]

http://edb.wsie.pl/files/3313/5288/1199/Skutki_migracji_dla_bezpieczestwa_wewntrznego.pd $\mathrm{f}[23.03 .2016 \mathrm{r}$.

[10] Otłowski T., Kto naprawdę stoi za falą migrantów szturmujących Europę? (Who is really behind the wave of migrants storming Europe?),

http://wiadomosci.wp.p1/kat,1356,title,Kto-naprawde-stoi-za-fala-migrantowszturmujacych-Europe,wid,17860501,martykul.html, [23.03.2016].

[11] www.tvn24.pl/wiadomosci-ze-swiata,2/zamachy-w-paryzu-podsumowanie,594420.html [13.03.2016].

[12] http://wyborcza.pl/1,75477,19123651,dzihad-wedrowny-zagraza-europie.html\#ixzz 40AAtTSFp [06.04.2016]. 